\title{
Signal Crayfish in Lake Saimaa Could be Maladapted to the Local Conditions Due to Aphanomyces astaci Infection: A Seven-Year Study
}

\author{
Japo Jussila, ${ }^{1, *}$ Vesa Tittinen, ${ }^{2}$ Lennart Edsman, ${ }^{3}$ Harri Kokko ${ }^{1}$ and Ravi Fotedar ${ }^{4}$ \\ ${ }^{1}$ Department of Environmental and Biological Sciences, University of Eastern Finland, P.O. Box 1627, 70210 Kuopio, Suomi-Finland. \\ ${ }^{*}$ Corresponding Author._japo.jussila@uef.fi \\ ${ }^{2}$ South Karelian Fisheries Advisory Center, Hietakallionkatu 2, 53850 Lappeenranta, Suomi-Finland. \\ ${ }^{3}$ Department of Aquatic Resources, Swedish University of Agricultural Sciences, 17893 Drottningholm, Sweden. \\ ${ }^{4}$ Environment and Agriculture, School of Science, Curtin University, Kent Street, Bentley, Western Australia 6102, Australia.
}

A B S T R A C T

We conducted a seven-year survey (years 2009 to 2015) of the Lake Saimaa signal crayfish population. Lake Saimaa is the largest single waterbody in Finland, with a productive fishery and crayfishery. The signal crayfish were introduced to Lake Saimaa in mid-1990's and a commercial fishery was initiated in the mid2000s. At first, there was a small proportion of noble crayfish among the catch, but after 2007, an acute crayfish plague epidemic eradicated them, and the signal crayfish stock started showing frequent gross symptoms of chronic crayfish plague infection (e.g., melanised lesions, eroded uropods and pleopods, lost appendages with melanised stumps). This stock now shows gross symptoms of the infection at a rate of $45 \%$ to $79 \%$ of the annual trap catch, in addition to showing signs of eroded swimmeret symdrome (ESS) at a rate of 2.8 to $15.4 \%$. The CPUE has remained rather low, between one and three crayfish throughout the survey, while the proportion of the commercial grade catch has been between $35 \%$ and $68 \%$ of the total catch. The signal crayfish populations in Lake Saimaa are still rather fragmented, and production is low. It appears that the Lake Saimaa signal crayfish population has developed slowly and is producing less than expected.

Copyright $(\mathcal{C} 2016$ by The Author(s). Published by the International Association of Astacology. This article is distributed under the terms of the Creative Commons Attribution License (CC-BY 4.0), which permits unrestricted use, distribution, and reproduction in any medium, provided the original author and source are credited.

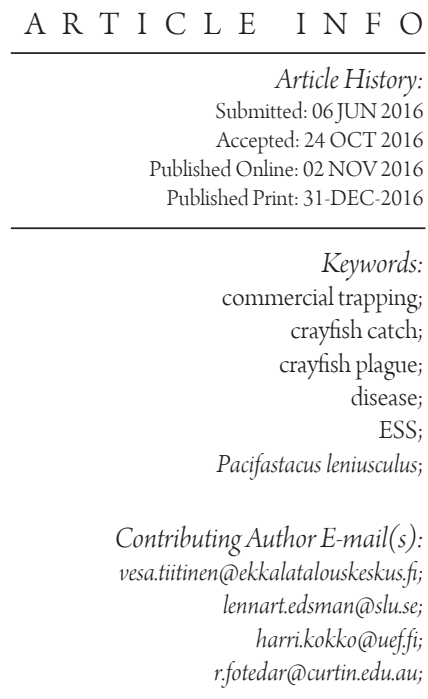

changes would have a great impact on them. Crayfish can be longlived, and individuals up to 20 years old can be found (Holdich and Lowery 1988; Belchier et al. 1998; Souty-Grosset et al. 2006), making them perfect organisms for assessing long-term changes in aquatic ecosystems. These features make crayfish excellent and sensitive candidates for environmental monitoring, as changes in aquatic ecosystem quality is quickly reflected in the state of the crayfish stock (Holdich and Lowery 1988; Kuklina et al. 2013).

The crayfisheries have traditionally been an important side income in rural regions in Fennoscandian countries (Jussila and Mannonen 2004) which has encouraged the fisheries administration to introduce alien signal crayfish from North America to substitute for the declining noble crayfish (Astacus astacus (Linné)) stocks (Souty-Grosset et al. 2006; Jussila et al. 2014a, 2015). This has created a situation where the large lakes, previously void of crayfish for decades, have been inhabited by introduced alien signal crayfish (Westman 2000; Holdich et al. 2009). The signal 


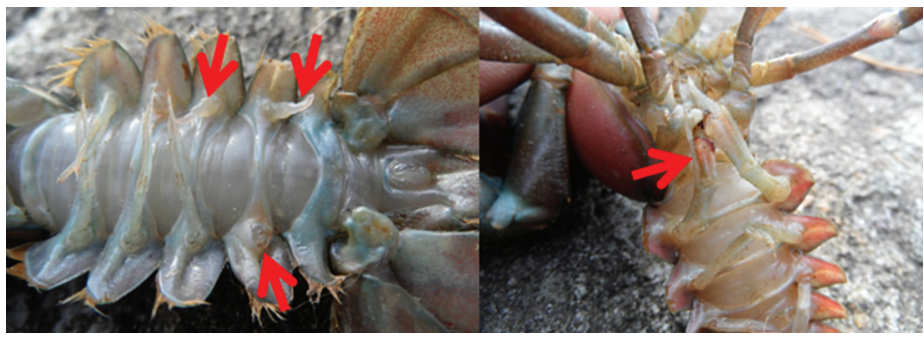

Figure 1. Eroded swimmeret syndrome (ESS) signs shown as regenerated swimmerets in a female (left) and eroded gonopods (pleopod 2) in a male signal crayfish (right) from Lake Saimaa.

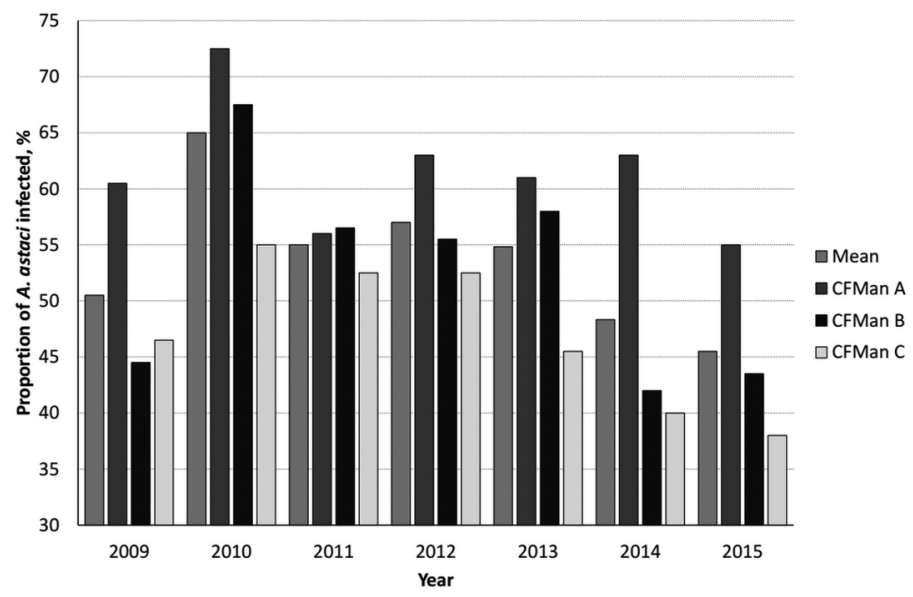

Figure 2. Percentages of $A$. astaci symptomatic signal crayfish in the catch from 2009 to 2015.

crayfish stocks have been recently reported to show maladaptation to Fennoscandian conditions, with several population crashes from both Sweden and Finland (Edgerton et al. 2004; Jussila et al. 2014a, 2015; Sandström et al. 2014) and also a recent discovery of a novel disease, eroded swimmeret syndrome (i.e., ESS), which is caused by a combined Fusarium SC and Aphanomyces astaci (Schikora) infection (Edsman et al. 2015). This partially complicates the population dynamic surveys of the signal crayfish, simultaneously making these stocks relatively more suitable for environmental monitoring with their perceived increased sensitivity to changes in the aquatic environment.

In Finland, losses among the noble crayfish stocks due to crayfish plague epidemics were supposed to be mitigated by introducing the alien signal crayfish into the waterbodies that had become unsuitable for noble crayfish (Westman 2000; Kirjavainen and Sipponen 2004). The reasons for introducing signal crayfish were based on the assumptions that the species was immune against $A$. astaci and thus would thrive under southern Fennoscandian conditions. However, recently it has been shown that the signal crayfish might not be as good a candidate as was originally expected, and it has been observed to be struggling in Fennoscandia (Aydin et al. 2014; Sandström et al. 2014, Edsman et al. 2015; Jussila et al. 2015). The signal crayfish is also a chronic carrier of $A$. astaci (Holdich et al. 2009; Jussila et al. 2015; Kozak et al. 2015) and is considered to be among the top 100 worst invasive alien species (EU 2016). Thus, the situation for signal crayfish in Fennoscandian, and in European aquatic ecosystems in general, has been re-evaluated with many recent publications casting serious doubts about the possibility of further introductions of this species (e.g., Holdich et al. 2009).

Lake Saimaa, a typically shallow, lacelike fragmented natural freshwater lake, is the largest lake in Finland and the fourth largest in Europe, with a surface area of $4,400 \mathrm{~km}^{2}$, mean depth of $17 \mathrm{~m}$ and total water volume of $36 \mathrm{~km}^{3}$ (Wikipedia 2015). Lake Saimaa has 13,710 islands and its shoreline is $14,850 \mathrm{~km}$ long (Wikipedia 2015). The lake was one of the original prime sites for crayfisheries around the turn of the $20^{\text {th }}$ century (Lehtonen 1975). Lake Saimaa was hit by a crayfish plague epidemic in 1893, which was the first reported epidemic in Finland (Lehtonen 1975; Alderman 1996). Since then, several episodes of crayfish plague epidemics were reported and the lake was never successfully restocked with the native noble crayfish (Lehtonen 1975).

The alien signal crayfish stock was introduced into Lake Saimaa during the first half of the 1990's, which initiated a low but gradual increase in productivity, while commercial and recreational trapping of the signal crayfish started at the turn of the millennium (Jussila et al. 2013, 2014a). For a few years, there were also low numbers of noble crayfish in the catch (Tiitinen 2015, personal communication). An acute crayfish plague epidemic was observed in 2007, with symptoms such as drastic decline in the catch and a total disappearance of noble crayfish from the catch. Since then, signal crayfish production has remained at a low level for the past eight years. Furthermore, Lake Saimaa signal crayfish have shown severe gross symptoms of a chronic crayfish plague infection, with melanised lesions, eroded uropods and pleopods, and lost appendages with melanised stumps (Strand et al. 2012; Jussila et al. 2013; Edsman et al. 2015), and the infection rate, detected by both qPCR and visual observations during surveys, is above the average among the Finnish signal crayfish stocks. A discovery of ESS during the 2011 season (Edsman et al. 2015) has only complicated matters further.

We describe here the nature of the Lake Saimaa signal crayfish population. This is done largely from the point of view of a commercial crayfishermen, with emphasis on the quality and quantity of the catch and the sustainable exploitation of the alien crayfish stock in Lake Saimaa.

\section{MATERIALS AND METHODS}

During a seven-year survey (2009 - 2015) we have been monitoring the catch of three commercial crayfishermen in Lake Saimaa as part of research and development projects on the crayfisheries, crayfish handling, and storage methods (e.g., Jussila et al. 2013). Data has been collected, and catch measurements have been made, from a) three crayfishermen (from here on CFMan A, B and C), b) two test sites per crayfisherman four times per season, i.e., 3 CFMen $\times 2$ test sites $\times 4$ catching times during an eight week period, and c) the total annual catch as reported by the crayfishermen for each trapping day individually, both the total catch and the commercial catch (commercial grade, $>10 \mathrm{~cm}$ total length, TL). The test trapping sites for each crayfisherman ( $\mathrm{N}=2)$ were selected at the beginning of the survey and it was agreed that the crayfishermen would be trapping at these sites throughout the 
season as part of their trapping routine. This was to ensure that trapping pressure would be comparable within each site from one year to another. Otherwise, the crayfishermen were moving their traps throughout the season from one site to another, except for fishing the test trapping sites continuosly.

The crayfishermen were using popular Rapu-Rosvo ${ }^{\circledR}$ (Pirate) traps, which are of an enlongated shape with entrances on two sides. The bait was normally frozen or fresh roach (Rutilus rutilus (Linné)), sometimes with special artificial crayfish bait. The bait was placed inside a small perforated container inside the trap.

The commercial catch criteria are the proportion of market size signal crayfish of premium quality, meeting the following criteria, minimum $10 \mathrm{~cm}$ TL with equal size claws and no visible damage or gross symptoms of crayfish plague infection (Jussila et al. 2013). The crayfishermen were using roughly 70 (CFMan A), 200 (CFMan B) and 500 (CFMan C) traps daily during the crayfishing season, ranging from 1,500 to 17,874 trap nights during the whole season per crayfisherman.

In total, 12,826 signal crayfish from the test trapping sites were measured, resulting in roughly 1,833 signal crayfish measurements annually. The following measurements were taken from the catch at test sites: carapace length (CL, mm), sex (male, female), claws (intact or not), glare gland development, gross symptoms of crayfish plague infection (rated as $0=$ no gross symptoms, $1=1$ -5 melanised lesions and all appendages intact, $2=5+$ melanised lesions or lost appendages and melanisation), signs of ESS (rated as $0=$ healthy swimmerets, $1=$ melanised swimmerets, $2=1-$ 7 lost swimmerets and $3=$ all swimmerets lost) and specific additional notes on such things as carapace hardness, females carrying eggs or remains of eggs, unusual hemolymph color, etc. Notes on ESS (Edsman et al. 2015) have been taken since the 2013 annual survey.

The catch per unit effort (CPUE) was calculated based on the total crayfish catch of individual crayfishermen over the whole crayfish season divided by their cumulative trapping effort (see formula below). The crayfishermen reported crayfish catch and number of traps used daily. For practical resasons, we also discuss CPUE as crayfish per trap-night, with the assumption that a $10 \mathrm{~cm}$ TL commercial size and quality signal crayfish weighs roughly $55 \mathrm{~g}$.

$$
\text { CPUE }=\left(\mathrm{C}_{1}+\mathrm{C}_{2}+\mathrm{C}_{3}+\ldots+\mathrm{C}_{\mathrm{n}}\right) /\left(\mathrm{T}_{1}+\mathrm{T}_{2}+\mathrm{T}_{3}+\ldots+\mathrm{T}_{\mathrm{n}}\right),
$$

where $\mathrm{C}_{1}$ is crayfish catch on day 1 of the crayfish season $(\mathrm{g})$ and $\mathrm{T}_{1}$ is number of traps in use on day 1 of the crayfish season.

We estimated the trends in the proportion of $A$. astaci infected signal crayfish in the annual catch of the two test trapping sites for each crayfisherman. We used regression analyses and selected the fit which had highest $\mathrm{R}^{2}$.

We used MS-Excel for data processing. The results are expressed as means with standard deviations when relevant.

\section{RESULTS}

The crayfishermen can be rated in three different categories according to their trapping effort: 1) recreational trapper (CFMan
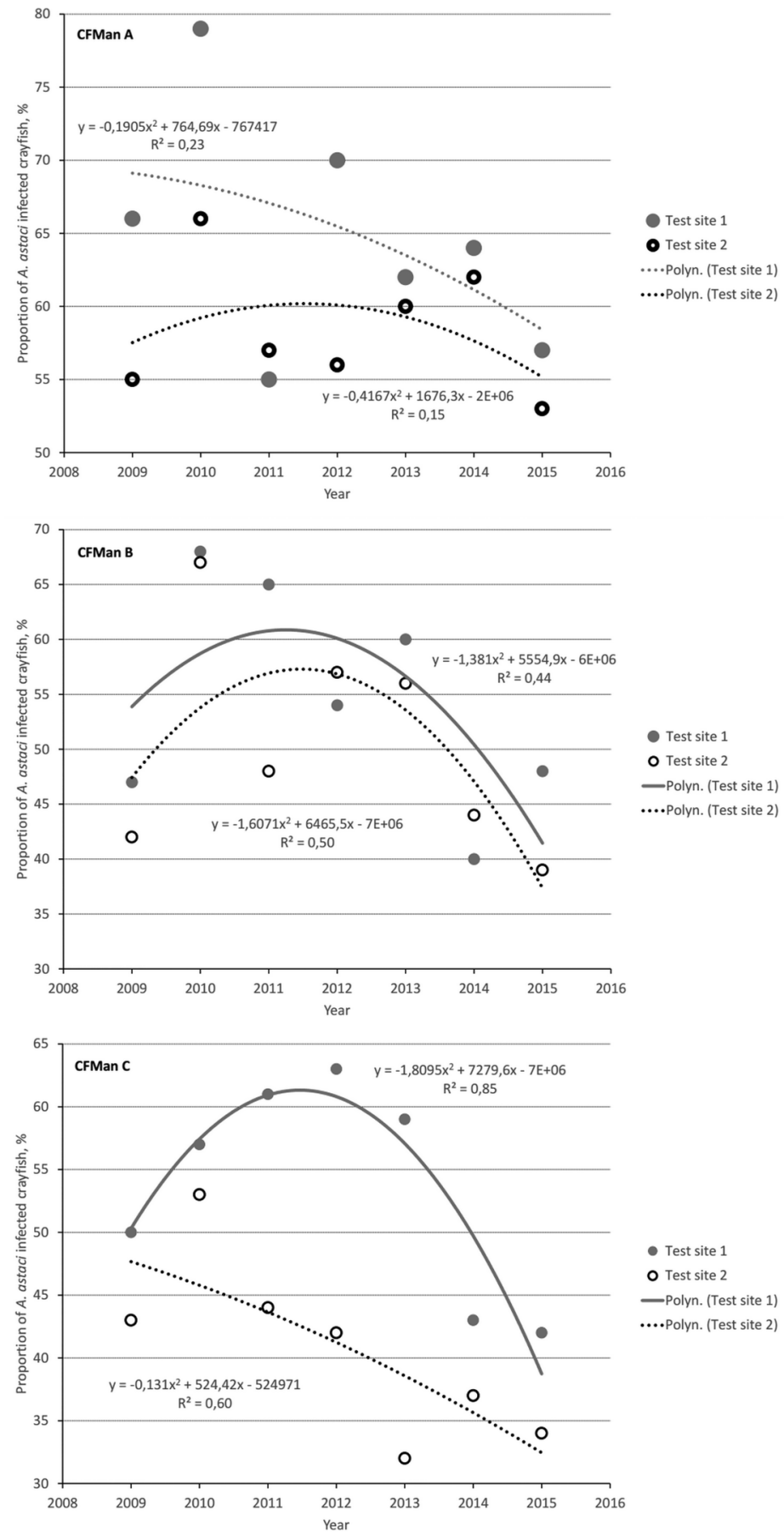

Figure 3. The proportion of the signal crayfish showing gross symptoms of the $A$. astaci infection among the test site catches annually. The annual mean is indicated by the dots for each of the crayfishermen per test trapping site per year. The trends were estimated using polynomial regression with the regression equation and $\mathrm{R}^{2}$ value displayed.

A), 2) semiprofessional trapper (CFMan B) and 3) professional trapper (CFMan C) (Table 1). These three different categories are well represented among the Finnish crayfish trappers, with the two latter normally selling most of their catch. The annual cumulative trapping effort was above 20,000 trap nights from 2010 onwards for the three test trappers.

We observed ESS among studied signal crayfish females annually and at all test trapping sites. The females have shown ESS 
Table 1. Total number of trap nights per crayfisherman during 2009-2015 based on the participating crayfishermen notes. Trap nights is the cumulative number of traps used daily during the crayfish season.

\begin{tabular}{lrrrrrrr}
\hline & \multicolumn{7}{c}{ Year } \\
\cline { 2 - 8 } & $\mathbf{2 0 0 9}$ & $\mathbf{2 0 1 0}$ & $\mathbf{2 0 1 1}$ & $\mathbf{2 0 1 2}$ & $\mathbf{2 0 1 3}$ & $\mathbf{2 0 1 4}$ & $\mathbf{2 0 1 5}$ \\
\hline CFMan A & 2,250 & 1,950 & 3,150 & 2,535 & 1,608 & 2,250 & 1,500 \\
CFMan B & 3,900 & 5,690 & 4,890 & 5,600 & 5,270 & 5,800 & 5,490 \\
CFMan C & 10,510 & 14,135 & 14,286 & 17,874 & 16,193 & 15,882 & 13,688 \\
\hline Sum & 16,660 & 21,775 & 22,326 & 26,009 & 23,071 & 23,932 & 20,678 \\
\hline
\end{tabular}

Table 2. Percentage of signal crayfish females showing eroded swimmeret syndrome (ESS) in Lake Saimaa test catches during 2013-2015 with the two test trapping sites separately displayed for each crayfisherman. Data based on test site catch measurements and observations. The ESS rating according to Edsman et al. (2015).

\begin{tabular}{|c|c|c|c|c|c|c|c|}
\hline & \multirow[b]{3}{*}{ ESS rating } & \multicolumn{6}{|c|}{ Year and Test Trapping Site } \\
\hline & & \multicolumn{2}{|c|}{2013} & \multicolumn{2}{|c|}{2014} & \multicolumn{2}{|c|}{2015} \\
\hline & & I & II & I & II & I & II \\
\hline \multirow{3}{*}{ CFMan A } & 1 & 42.9 & 27.2 & 28.4 & 29.4 & 21.6 & 28.4 \\
\hline & 2 & 14.3 & 9.1 & 11.3 & 13.0 & 15.0 & 10.5 \\
\hline & 3 & 0.0 & 0.0 & 0.0 & 0.0 & 0.0 & 0.0 \\
\hline \multirow[t]{3}{*}{ CFMan B } & 1 & 56.7 & 11.1 & 24.4 & 27.3 & 18.5 & 20.3 \\
\hline & 2 & 6.7 & 2.8 & 15.3 & 15.4 & 10.1 & 15.4 \\
\hline & 3 & 0.0 & 0.0 & 0.0 & 0.0 & 0.0 & 0.0 \\
\hline \multirow[t]{3}{*}{ CFMan C } & 1 & 5.3 & 15.6 & 16.3 & 20.1 & 28.9 & 14.5 \\
\hline & 2 & 5.2 & 9.4 & 8.9 & 5.8 & 3.5 & 7.7 \\
\hline & 3 & 0.0 & 0.0 & 0.0 & 0.0 & 0.0 & 0.0 \\
\hline
\end{tabular}

signs at a rate of $10.5-63.4 \%$ (Table 2 ) with no detection of a total loss of swimmerets among the female crayfish caught at test sites. The proportion of ESS (stage 2 and 3 ) in female crayfish ranged from 2.8 to $15.4 \%$ in the test catch. We have also observed that the eroded swimmerets were regenerated in some females (Figure 1). Furthermore, during the 2015 survey, a few male individuals with eroded pleopods (1 and 2) and swimmerets were observed (Figure 1). Females with eroded swimmerets in the test catches also showed indications of a longer hatching period of the eggs, as only those signal crayfish females that had ESS still had eggs or second stage juveniles under their tail in early August 2015.

The annual mean proportion of the signal crayfish showing gross symptoms of $A$. astaci infection were on average higher than $40 \%$ in the test site catches (Figure 2), except for test site catches for CFMan B in 2014 and 2015 and for CFMan C in 2013, 2014 and 2015. The highest pooled mean annual proportion of $A$. astaci infected signal crayfish was in CFMan A's catch, reaching 61.6 $\pm 7.1 \%$. The lowest pooled mean annual proportion of $A$. astaci infected signal crayfish were in CFMan C's catch, averaging 47.1 $\pm 10.1 \%$. CFMan B had an average of $52.5 \pm 10.0 \%$ infected signal crayfish in his test site catch. The proportion of infected signal crayfish was statistically significantly higher among CFMan A's catch compared to both CFMan B's and CFMan C's catch (t-test, $\mathrm{p}<0.05)$ while there was no difference between CFMan B's and CFMan C's catch. After an initial increase for 2 to 3 years, there was a general declining trend over time in the proportion of signal crayfish showing gross symptoms of $A$. astaci infection (Figure 3 ), with a polynomial fit curve showing the highest correlation $\left(\mathrm{R}^{2}\right)$ in all cases. The fit curves $\mathrm{R}^{2}$ values were low for CFMan A data (from 0.1 to 0.2 ), while $\mathrm{R}^{2}$ values showed moderate to high significance in CFMan B and C data, being from 0.4 to 0.5 and from 0.6 to 0.8 , respectively. There was considerable year to year variation in the proportion of infected signal crayfish in our survey.

The average catch per unit effort (CPUE, g of crayfish per trap night), estimated from the crayfishermen's annual catch statistics, increased from $58 \mathrm{~g}$ (in 2009) to $135 \mathrm{~g}$ (in 2012) and then levelled off for the rest of the survey period at above $120 \mathrm{~g}$ (Figure 4). This maximum average CPUE roughly equals 1.5 commercial sized signal crayfish, and for practical reasons, we will be discussing CPUE as the number of crayfish per trap-night in the Discussion section. Overall, CFMan B had the highest CPUE, except for the year 2011, and CFMan A had the lowest CPUE, except for the year 2009. The CPUE was increasing throughout the survey for CFMan B, except in 2015, while CPUE leveled off for both CFMan A and CFMan C after 2011.

Catch data for CFMan C, collected prior to this survey, indicates that the average CPUE over the whole crayfish catching season was $59 \mathrm{~g}$ of crayfish per trap night in 2006, $21 \mathrm{~g}$ in 2007 and $33 \mathrm{~g}$ in 2008. During 2007, an acute crayfish plague epidemic was observed in Lake Saimaa (Jussila et al. 2013, 2014a) and the signal crayfish were rather lethargic with elevated levels of 
mortality during transport to processing sites (Tiitinen 2015, personal communication).

The proportion of grade I market-size signal crayfish, estimated using crayfishermen annual catch statistics, averaged roughly $40 \%$ in the commercial catch during 2010 and 2011, with a slight increasing trend throughout the monitoring period (Figure 5). The proportion of market-size signal crayfish in the catch was highest for CFMan A, except for 2014, when the differences among the test trappers were small. CFMan $\mathrm{C}$ always caught the smallest proportion of market size crayfish during the survey period. The variation in the proportion of market-sized signal crayfish for each crayfisherman catch was lowest during 2014 and 2015, while higher levels of variation were evident during 2010 2013. The proportion of market-sized signal crayfish in the catch was 1.5 times higher for CFMan A compared to CFMan C during 2011-2013.

\section{DISCUSSION}

We have shown that Lake Saimaa signal crayfish are suffering from chronic Aphanomyces astaci infection at a high rate, with up to $79 \%$ of the commercial catch showing gross symptoms of crayfish plague infection. The lowest annual mean proportion of market quality signal crayfish among the commercial trapper catch was $45 \%$. The proportion of the market size signal crayfish (i.e., over $10 \mathrm{~cm} \mathrm{TL}$ ) is rather high in the commercial crayfishermen catch in Lake Saimaa, especially considering that the stock is heavily exploited. On the other hand, the CPUE has remained low so far, equaling roughly a maximum of three commercial size signal crayfish. All this information combined shows that the Lake Saimaa signal crayfish population production potential has remained rather low.

A high proportion of signal crayfish displayed gross symptoms of $A$. astaci infection, averaging between $47 \%$ and $62 \%$ among the test site catches. Previously, it has been reported that the prevalence of $A$. astaci infection in Lake Saimaa signal crayfish might be as high as 90\%, based on TagMan qPCR analyses (Strand et al. 2012). This is higher than the gross symptoms proportion observed in our survey data, which could indicate that some of the infected signal crayfish might not be detected during the field surveys. Surveys in two other Finnish signal crayfish populations indicate that roughly $24 \%$ of the signal crayfish were showing gross symptoms of $A$. astaci infection (Nylund and Westman 2000), ranging from $10 \%$ to $63 \%$ in their data. In general, the signal crayfish $\mathrm{A}$. astaci infection prevalence at the population level varies, and even healthy populations have been reported from Europe (Kozubíková et al. 2009; Filipová et al. 2013). The high infection prevalence in our survey data might affect the survival of the Lake Saimaa signal crayfish. It has been shown earlier that the signal crayfish is not indifferent to this disease and it may show increased mortality when infected (Thörnqvist and Söderhäll 1993; Aydin et al. 2014; Jussila et al. 2014a). The high prevalence of $A$. astaci infected signal crayfish could be a factor behind the low CPUE observed in our survey data.

On the other hand, we observed a declining trend in the proportion of signal crayfish showing gross symptoms of crayfish

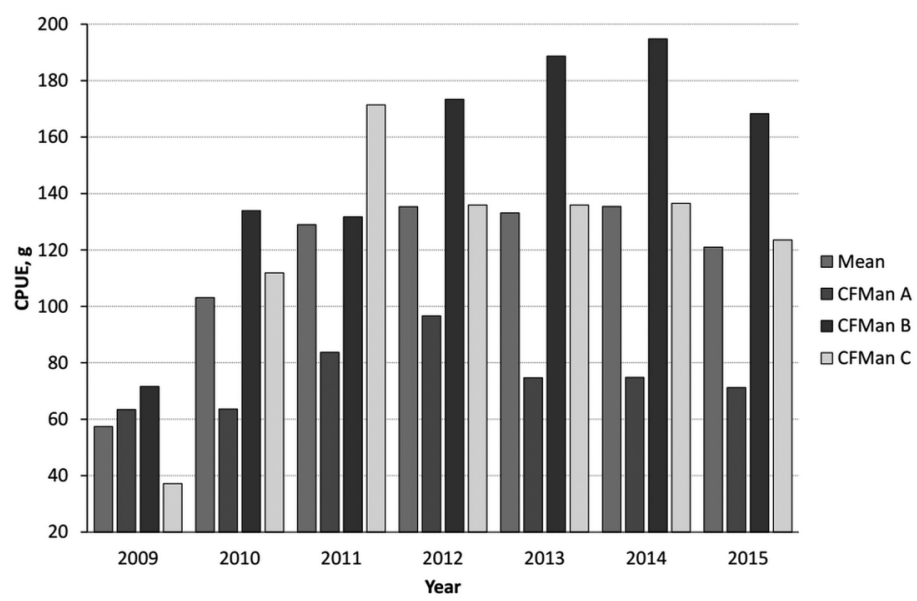

Figure 4. Estimated catch per unit effort (CPUE) based on the catch reports by the crayfishermen over seven years. CPUE expressed as $g$ of crayfish per trap-night for the whole crayfish season. Daily crayfish catch (g) and number of traps (\#) used obtained from the annual reports of the crayfishermen.

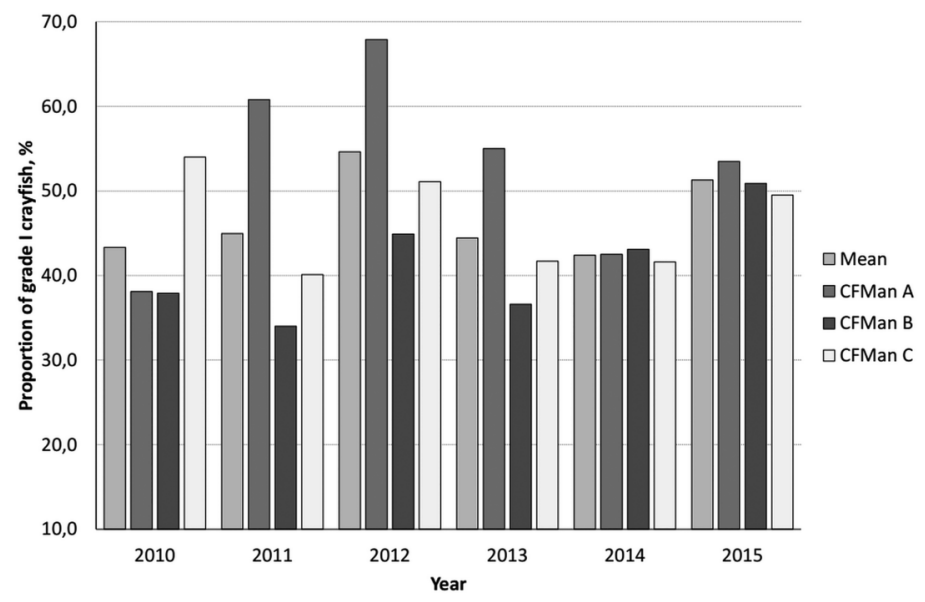

Figure 5. Proportion of market quality signal crayfish in the annual catch, i.e., signal crayfish fulfilling the criteria of minimum size $10 \mathrm{~cm}$ TL and no gross symptoms of $A$. astaci infection. Data for the whole crayfish season and obtained from the annual reports of the crayfishermen.

plague infection in our data over time. This finding should be treated with caution, since the trend line $\mathrm{R}^{2}$ values were less than 0.5 in half of the cases. Furthermore, the data indicated large annual variation in the proportion of the infected crayfish, which might be the main finding here. Considering this, the effect of $A$. astaci infection prevalence and the possibility of an improved resistance among wild signal crayfish is an interesting phenomenon.

The proportion of female signal crayfish showing signs of ESS is comparable to our previous data from Finland (Edsman et al. 2015), but lower than observed in that study among collapsed signal crayfish populations in Sweden. In our data, we did not observe any females with complete swimmeret losses and also found evidence of swimmeret regeneration. Thus, there is a possibility for recovery among those female signal crayfish that do not die due to ESS and $A$. astaci infection. However, our laboratory experiment showed that even partially regenerated swimmerets are not suitable for carrying eggs during hatching and thus cause loss 
of the reproductive output at the population level (unpublished data).

The maximum proportion of the signal crayfish females suffering from stage 2 ESS was $15.4 \%$ in our survey. This could cause an estimated loss of $10 \%$ in the reproductive output at the population level. It has been suggested that ESS (caused by a combination of Fusarium SC and $A$. astaci infection), could be a biotic factor capable of controlling alien signal crayfish populations in Fennoscandian waters. This is an interesting speculative statement, as it has been reported elsewhere that several Fennoscandian signal crayfish stocks have crashed or decreased in size (Aydin et al. 2014; Jussila et al. 2014a, Sandström et al. 2014), contrary to what was earlier assumed. We have also observed that male signal crayfish can have eroded swimmerets and gonopods in Lake Saimaa. In addition, we have not observed ESS or any similar symptoms in noble crayfish (Astacus astacus) in Fennoscandia. The direct effects of ESS on signal crayfish viability and juvenile recruitment warrants further investigation.

For practical reasons, we are discussing CPUE in terms number of crayfish, even though the crayfishermen have reported only the total weight of their catch. The average CPUE in the commercial catch, for all size classes, fell between 1 and 3 crayfish throughout the survey period, indicating that Lake Saimaa signal crayfish population density is rather low, but still productive, and that the population might be in its growth stage, with low competition for resources. Previously, it has been reported that the development of the signal crayfish fishery might take decades, with estimates that CPUE could exceed 1 only after 20 years (Kirjavainen and Westman 1999; Westman 2000), while higher CPUEs have been observed in Europe (Guan 2000; Nyström et al. 2006; Capurro et al. 2007; Peay et al. 2009). It must be remembered that the sampling in our survey was not neutral, but rather based on effort of commercial trappers to maximize their catch. Even when the crayfish trappers are constantly reviewing their effort and aiming for cost effectiveness, the average CPUE over the season remained low, quite close to the threshold of the crayfish population being exploited (Erkamo et al. 2010; Jussila et al. 2014a). On the other hand, there were distinct differences among the test trappers and the two trappers having the highest effort (CFMan B and C) also had roughly double CPUE compared to the recreational trapper (CFMan A). Even for CFMan B and C, the best CPUE remained between 2 and 3 crayfish during the survey period.

The proportion of market size (over $10 \mathrm{~cm} \mathrm{TL}$ ) signal crayfish in the Lake Saimaa catch has remained high throughout the survey period, at the level of $40 \%$ to $50 \%$ on average. This is in spite of the commercial trappers using largely the same areas for trapping from one season to next. On the other hand, the individual commercial trapping sites cover large areas and Lake Saimaa itself allows plenty of habitat for the signal crayfish. It may be that crayfishermen are actively moving within each individual site while trapping, and abandoning sites of low production and moving to more productive ones. It could also be that the signal crayfish stock is still in its growth stage after 20 years and low density populations allow for faster growth. Finally, there is also the option of low juvenile recruitment and low mortality of juveniles, which results in a higher proportion of larger sized individuals but low overall CPUE in the commercial catch. The effect of long-term trapping pressure usually tends to drive towards smaller mean size (Momot 1991; Tulonen et al. 2008) but this does not show in our data and it can be partially explained by the trapping strategy of the commercial trappers aiming for the highest cost effectiveness in the crayfishery. Alternative scenarios have also been suggested as the outcome of the exploitation (Momot 1991; Huner and Lindqvist 1988). Thus, there are several possible factors that can skew the size distribution towards larger size crayfish in Lake Saimaa, but there is also room for further investigations.

The first years of the follow-up period showed an increase in CPUE among the catch of the test trappers, and after 2011, the CPUE leveled off at roughly 2 crayfish. The Lake Saimaa crayfish population, which also included noble crayfish at that time, experienced a crayfish plague epidemic in 2007 (Jussila et al. 2013, 2014b). Due to the epidemic, the CPUE declined to less than half the current rate (according to catch records from one test trapper), with those crayfish caught showing high lethargy compared to previous years. Thus, the initial increase in CPUE in our survey data during 2009 and 2010 could still be within the recovery phase from the 2007 crayfish plague epidemic. The leveling of the CPUE after 2011 might be indicating that the production capacity of Lake Saimaa signal crayfish may have been reached at a level that is quite low. Alternatively, the Lake Saimaa signal crayfish stock may still be in the low density growth phase, since Lake Saimaa is a large waterbody and, with the signal crayfish stock having been established only recently in the early to mid 1990s, it could take decades to reach carrying capacity within the lake.

In conclusion, our research indicates that the Lake Saimaa signal crayfish stock is showing indications of alien species maladaptation to environmental conditions in Fennoscandia, as it is heavily affected by $A$. astaci infection and suffering from ESS. It is also obvious that the CPUE has remained comparatively low in Lake Saimaa, but investigations of reasons for the low CPUE were beyond the scope of this study. It appears that the success of alien species introductions, when introduced into new regions, should only be evaluated after a lengthy time lag, which in this case would be several decades. Thus, similarities between habitat conditions in the native range of the species and its sites of introduction should be examined with extreme caution. These often positively biased preassumptions should not be used as a basis for decision-making per se, but should be weighed carefully against the principle of caution in introducing alien species.

\section{ACKNOWLEDGMENTS}

We are thankful to the crayfishermen in Lake Saimaa for their hospitality and the grit they exhibit under the unpredictable elements of the Finnish summer. The survey has been partially funded by the Southeastern ELY-Center using funds for fisheries compensations. LIFE+ CrayMate project (LIFE12 INF/FI/233) has partially funded this survey. Several of our colleagues have participated in the data collection and we wish to thank David Strand (Norway), Jörn Panteleit (Germany) and Hamdi Aydin (Turkey) for their professionalism during the field trips. Hobo Kukkonen (Kuopio) did some of the data processing. 


\section{LITERATURE CITED}

ALDERMAn DJ (1996). Geographical spread of bacterial and fungal diseases of crustaceans. Revue Scientifique et Technique 15(2):603-632.

Aydin H, Kokko H AND Makkonen J (2014). The signal crayfish is vulnerable to both the As and the PsI-isolates of the crayfish plague. Knowledge and Management of Aquatic Ecosystems 413:03.

Belchier M, Edsman L, Sheeny MRJ And Shelton PMJ (1998). Estimating age and growth in long-lived temperate freshwater crayfish using lipofuscin. Freshwater Biology 39(3):439-446.

Bohman P, Nordwall F and Edsman L (2006). The effect of the large-scale introduction of signal crayfish on the spread of crayfish plague in Sweden. Bulletin Français de la Pêche et de la Pisciculture 380-381:1291-1302.

Capurro M, Galli L, Mori M, Salvidio S and Arillo A (2007). The signal crayfish, Pacifastacus leniusculus (Dana, 1852) [Crustacea: Decapoda: Astacidae], in the Brugneto Lake (Liguria, NW Italy). The beginning of the invasion of the River Po watershed? Aquatic Invasions 2(1):17-24.

Edgerton BF, Henttonen P, Jussila J, Mannonen A, PaAsonen P, Taugbøl T, Edsman L and Souty-Grosset C (2004). Understanding the causes of disease in European freshwater crayfish. Conservation Biology 18(6):1466-1474.

Edsman L, Nyström P, Sandström A, Stenderg M, Kokko H, Tittinen V, Makkonen J and Jussila J (2015). Eroded swimmeret syndrome in female crayfish Pacifastacus leniusculus associated with Aphanomyces astaci and Fusarium spp. infections. Diseases of Aquatic Organisms 112(3):219228.

ERCOLI F (2014). A comparison of the impacts of introduced signal crayfish and native noble crayfish in boreal lake ecosystems. Jyväskylä, Finland. Doctoral Dissertation, University of Jyväskylä.

ERKamo E, Ruokonen T, Alapassi T, RUOKolainen J, JärVENPÄÄ T, Tulonen J and KirJavainen J (2010). Evaluation of crayfish stocking success in Finland. Freshwater Crayfish 17:77-83.

EU (2016) EU Regulation 1143/2014. http://eur-lex.europa. eu/legal-content/EN/TXT/?uri=OJ\%3AJOL_2014_317 _R_0003. [accessed 2 October 2016]

Filipová L, Petrusek A, Matasová K, Delaunay C and Grandjean F (2013). Prevalence of the crayfish plague pathogen Aphanomyces astaci in populations of the signal crayfish Pacifastacus leniusculus in France: Evaluating the threat to native crayfish. PLOS ONE 8(7):e70157.

GuAN R-Z (2000). Abundance and production of the introduced signal crayfish in a British lowland river. Aquaculture International 8(1):59-76.

Holdich DM AND Lowery RS (eds.) (1988). Freshwater Crayfish. Biology, Management and Exploitation. Croom Helm, London, UK.
Holdich DM, Reynolds JD, Souty-Grosset C and Sibley PJ (2009). A review of the ever increasing threat to European crayfish from non-indigenous crayfish species. Knowledge and Management of Aquatic Ecosystems 394-395:11.

HUNER JV AND LINDQVIST OV (1988). Response of a slow growing noble crayfish, Astacus astacus L., population from a pond in Central Finland to several years of exploitation. Freshwater Crayfish 7:81-89.

Jussila J And Mannonen A (2004). Crayfisheries in Finland, a short overview. Bulletin Français de la Pêche et de la Pisciculture 372-373:263-273.

Jussila J, Tiitinen V, Fotedar R and KoKko H (2013). A simple and efficient cooling method for post-harvest transport of the commercial crayfish catch. Freshwater Crayfish 19(1):15-19.

Jussila J, Makkonen J, Kokko H and Mäkinen P (2014a). Numerous population crashes of wild signal crayfish (Pacifastacus leniusculus) in Southern Finland. Freshwater Crayfish 19(1):73-79.

Jussila J, Makkonen J, Vainikka A, Kortet R and Kokko H (2014b). Crayfish plague dilemma: how to be a courteous killer? Boreal Environment Research 19(3):235-244.

Jussila J, Maguire I, Kokko H, Kortet R and Makkonen J (2015). Chaos and adaptation in the host-pathogen relationship in relation to the conservation: the case of the crayfish plague and the noble crayfish. Pp. 246-274, In: Freshwater Crayfish: Global Overview. Kawai T, Faulker Z, Scholtz G (ed.). Science Publishers, USA.

KIRJAVAINEN J AND SIPPONEN M (2004). Environmental benefit of different crayfish management strategies in Finland. Fisheries Management and Ecology 11(3-4):213-218.

KirJaVAinen J AND Westman K (1999). Natural history and development of the introduced signal crayfish, Pacifastacus leniusculus, in a small, isolated Finnish lake, from 1968 to 1993. Aquatic Living Resources 12(6):387-401.

Kozak P, Ďuriš Z, Petrusek A, Bư̌ič M, Horká I, Kouba A, Kozubíková-Balkarová E and Policar T (2015). Crayfish Biology and Culture. University of South Bohemia, České Budějovice, Vodňany, Czech Republic.

Kozubíková E, Filipová L, KozÁK P, Duuriš Z, Martín MP, Diéguez-Uribeondo J, Oidtmann B and Petrusek A (2009). Prevalence of the crayfish plague pathogen Aphanomyces astaci in invasive American crayfishes in the Czech Republic. Conservation Biology 23(5):1204-1213.

KuKLINA I, Kouba A AND KozÁk P (2013). Real-time monitoring of water quality using fish and crayfish as bio-indicators: a review. Environmental Monitoring and Assessment 185:50435053.

Lehtonen JUE (1975). Kansanomainen ravustus ja rapujen hyväksikäyttö Suomessa. (English: Common catching habits and utilisation of crayfish in Finland). Tapiola, Suomi-Finland: Oy Weilin+Göös Ab. [In Finnish].

Момот WT (1991). Potential for exploitation of freshwater crayfish in coolwater systems: management guidelines and issues. Fisheries 16(5):14-21. 
Nylund V AND Westman K (2000). The prevalence of crayfish plague (Aphanomyces astaci) in two signal crayfish (Pacifastacus leniusculus) populations in Finland. Journal of Crustacean Biology 20(4):777-785.

Nyström P, Stenroth P, Holmqvist N, Berglund O, Larsson P AND GRANÉLI W (2006). Crayfish in lakes and streams: individual and population responses to predation, productivity and substratum availability. Freshwater Biology 51(11):20962113.

Peay S, Guthrie N, Spees J, Nilsson E and Bradley P (2009). The impact of signal crayfish (Pacifastacus leniusculus) on the recruitment of salmonid fish in a headwater stream in Yorkshire, England. Knowledge and Management of Aquatic Ecosystems 394-395:12.

RUOKONEN T (2012). Ecological impacts of invasive signal crayfish in large boreal lakes. Jyväskylä, Finland. Doctoral Dissertation, the University of Jyväskylä.

Sandström A, Andersson M, Asp A, Bohman P, Edsman L, Engdahl F, Nyström P, Stenberg M, Hertonsson P, VRÅlstad T and Granéli W (2014). Population collapses in introduced non-indegenous crayfish. Biological Invasions 16(9):1961-1977.

Souty-Grosset C, Holdich DM, NoËL PY, Reynolds JD AND HAFFner P (eds.) (2006). Atlas of crayfish in Europe. Paris, France: Muséum national d'Historie naturelle.

Strand D, Jussila J, ViljamaA-Dirks S, Kokko H, Makkonen J, Holst-Jensen A, Viljugrein H and VRÅLstad T (2012). Monitoring the spore dynamics of Aphanomyces astaci in the ambient water of latent carrier crayfish. Veterinary Microbiology 160(1-2):99-107.

THÖRnQVist P-O AND SöDERHÄLl K (1993). Psorospermium haeckeli and its interaction with the crayfish defence system. Aquaculture 117(3-4):205-213.

TitTinen V (2015). Etelä-Karjalan kalatalouskeskus, Lappeenranta, Suomi-Finland. Personal communication.

Tulonen J, Erkamo E, Jussila J and Mannonen A (2008). The effects of minimum size regulations and exploitation on population dynamics of noble crayfish (Astacus astacus (Linnaeus)) in a small lake in Central Finland: A seven year study. Freshwater Crayfish 16:7-14.

Westman K (2000). Comparison of the crayfish Pacifastacus leniusculus Dana, a species introduced to Finland, with the native species, Astacus astacus L., in allopatry and sympatry. $\mathrm{PhD}$ Dissertation. University of Helsinki, Helsinki, Suomi Finland.

WiKIPEDIA (2015). Saimaa. [accessed 17 December 2015]. 